\title{
A Case of the Ex Utero Intrapartum Treatment in Congenital Fetal Oral Teratoma
}

\author{
Seong Jun Won ${ }^{1}$, Jin Pyeong Kim ${ }^{1}$, Jung Je Park ${ }^{1}$, and Seung Hoon Woo ${ }^{1,2}$ \\ ${ }^{1}$ Department of Otorhinolaryngology, ${ }^{2}$ Institute of Health Sciences, College of Medicine, Gyeongsang National University, Jinju, Korea
}

\section{선천성 태아 구강 기형종에서의 분만 중 자궁외 치료 1예}

원성준 ${ }^{1} \cdot$ 김진평 $^{1} \cdot$ 박정제 $^{1} \cdot$ 우승 훈 ${ }^{1,2}$

경상대학교 의과대학 이비인후과학교실, ${ }^{1}$ 건강과학원 ${ }^{2}$

\author{
Received June 26, 2014 \\ Revised August 22,2014 \\ Accepted August 22, 2014 \\ Address for correspondence \\ Seung Hoon Woo, MD \\ Department of Otorhinolaryngology, \\ College of Medicine, \\ Gyeongsang National University, \\ 79 Gangnam-ro, Jinju 660-702, \\ Korea \\ Tel $+82-55-750-8173$ \\ Fax $+82-55-759-0613$ \\ E-mail lesaby@hanmail.net
}

The ex utero intrapartum treatment (EXIT) is used for unborn fetuses in cases of predictable complications of postpartum airway obstruction. The delivered fetus is maintained on placental circulation while airway is established and this is carried out by a multidisciplinary team. Teratomas arising from the palate or pharynx may cause immediate life-threatening airway obstruction to the newborn. In our case, congenital oral teratoma was detected via prenatal ultrasound. The treating team determined that this may induce airway occlusion at birth and decided to perform an EXIT to secure an airway. On the day of birth, debulking of the tumor was performed and the fetus was successfully delivered. Vital signs were stable without intubation management. Korean J Otorhinolaryngol-Head Neck Surg 2015;58(7):487-91

\section{서 론}

Ex utero intrapartum treatment(EXIT)는 제왕절개술 동 안에 자궁-태반 순환을 유지하면서 태아의 기도를 확보하는 방법이다. ${ }^{1,2)}$ EXIT는 분만 후 즉시 기도폐색이 발생할 가능성 이 있거나 심장·호흡기의 문제를 의심할 수 있는 모든 태아에 적용될 수 있다. 경부종물, 구강 및 구인두의 종물, 심한 소악증 (micrognathia), congenital high airway obstruction syndrome, 폐의 병변, 종격동 종물, 분만 직후에 체외막산소화장 치(extracorporal membrane oxygenation, ECMO)를 사용해 야 하는 경우 등에 사용되고 있다. ${ }^{3-6)}$ EXIT를 진행하는 동안 기관지경, 기도삽관, 기관절개술, 후두현수경, 종물의 제거 등 다양한 방법으로 태아의 기도를 확보할 수 있다.

선천성 기도폐쇄를 유발할 수 있는 여러 원인 중 기형종(teratoma)은 생존아 20000 내지 40000명당 1명의 발생률을 가 지며 특히 안면 및 두경부 기형종은 전체 기형종의 $5 \%$ 를 차지 하는 매우 드문 질환이다. ${ }^{67)}$ 안면 및 두경부 기형종에 의해 기
도폐색의 발생 위험성이 있는 태아의 치료에 EXIT가 사용된 다. ${ }^{6,7)}$ 저자들은 선천성 태아 구강 기형종 치료 시 EXIT를 시 행하였고 자궁-태반순환이 유지되는 동안 종물을 직접 제거 하여 기도를 확보한 1 예를 경험하였기에 문헌고찰과 함께 보 고하는 바이다.

\section{증 례}

32 세 여자 환자가 임신 37 주 5 일에 개인 산부인과에서 시행 한 산전 초음파상 태아 구강 내의 종물을 의심하여 본원으로 전원 되었다. 산전 초음파상 양수지수는 $7.58 \mathrm{~cm}$, 태아몸무 게, 대퇴부길이, 머리둘레, 배둘레 등은 36 37주 수준이었으 며 구강 내로 $3 \times 3 \times 3.5 \mathrm{~cm}$ 크기의 종물이 발견되었다(Fig. 1). 다른 해부학적 기형은 관찰되지 않았다. 이전 시행한 산전 검 사상 특이사항은 없었으며 산모는 2011년 12월 정상분만으 로 여아를 분만한 1 회의 출산력 외에 과거력 및 가족력상 특 이사항은 없었다. 분만 시 태아의 기도폐색 가능성이 높아 산 
부인과, 소아과, 이비인후과, 소아외과, 마취통증의학과 의사 가 협진하여 EXIT를 시행하기로 결정하였다. 세부적으로 산 모의 전신마취, 자궁-태반순환의 유지, 태아 만출 후 기도확보 방법, 기도확보 후 태아의 관리에 대해 논의되었다. 또 분만 시 발생할 수 있는 상황을 고려하여 수혈준비, 기도삽관 또는 후 두현수경을 통한 기도확보, 필요 시 즉각 종물 제거를 통한 기 도확보 등의 시나리오를 상정하여 준비하였고 산부인과, 소 아과, 마취통증의학과, 이비인후과가 팀으로 수술에 참여하기 로 결정되었다.

임신 38주에 제왕절개법을 통한 분만을 시행하였다. 산모는 누운 상태에서 $100 \%$ 산소로 denitrogenation 시킨 후 propo-

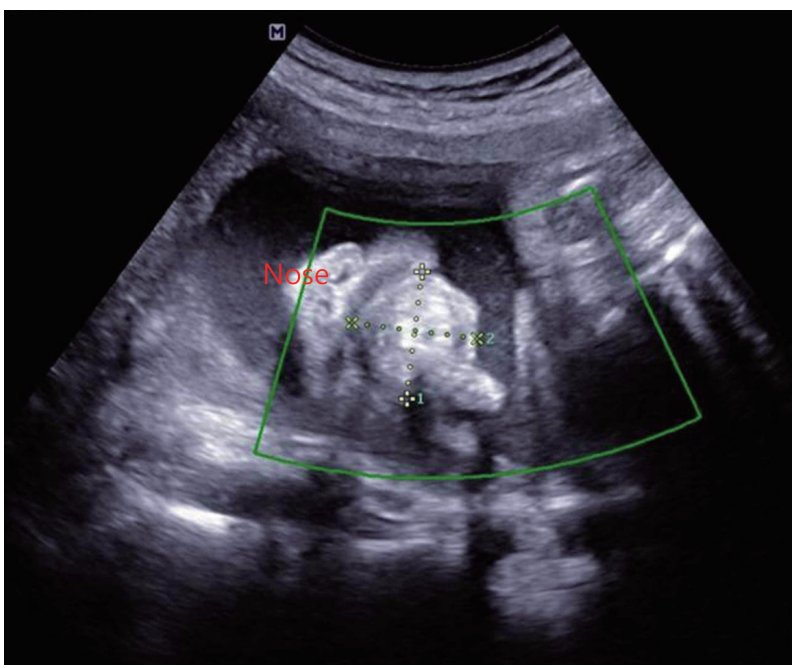

Fig. 1. Fetal sonography image at $37+5$ weeks gestation. This image shows a fetal oropharyngeal mass the oral which is filling cavity. Its' size is $3.0 \times 3.0 \mathrm{~cm}$ in diameter. fol $120 \mathrm{mg}$ 를 정맥 주사하여 수면을 유도하였다. Sevoflurane 으로 흡입마취를 시행하면서 succinylcholine, rocuronium 정맥주사 후 기도삽관을 시행하였다. 제왕절개를 시작하여 자궁에 절개를 넣고 태아를 만출하였고 태아에서 구강을 완 전히 막고 있는 종물을 확인할 수 있었다(Fig. 2). 태아의 종 물을 확인하고 기도삽관은 어렵다는 판단을 하였고 즉각 종 물을 제거하고 기도를 확보하기로 결정하였다.

태아 만출 후 즉시 대기하고 있던 이비인후과 의사에 의해 구강 내 종물을 제거하는 수술을 시행하였다(Fig. 3). 구강을 완전히 채운 경구개에서 기시된 종물을 확인할 수 있었고, 국

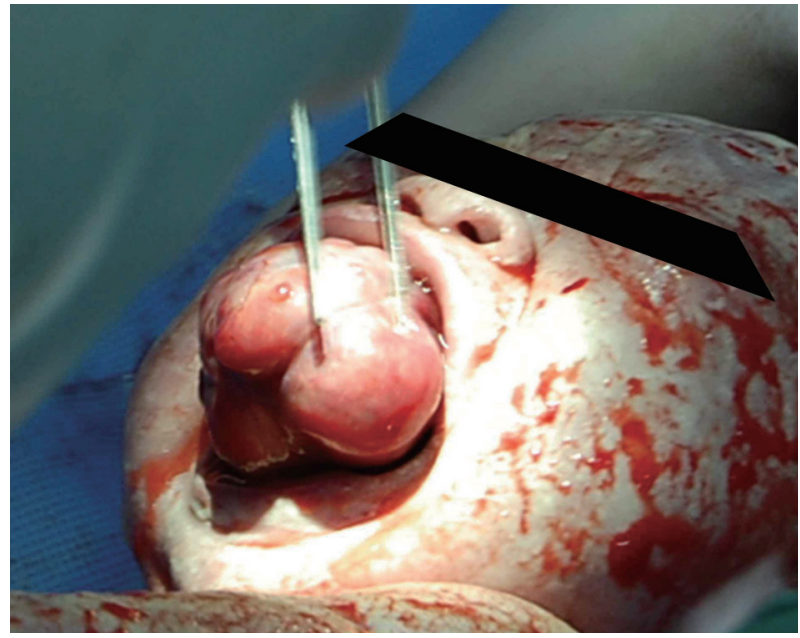

Fig. 2. After exposing the fetus, evaluation of the oral tumor was performed by the ex utero intrapartum treatment team. Possibility of an airway obstruction was high due to a $3.0 \times 3.0 \times 3.5$ size oral tumor. To secure the airway, the EXIT team chose to excise the tumor.
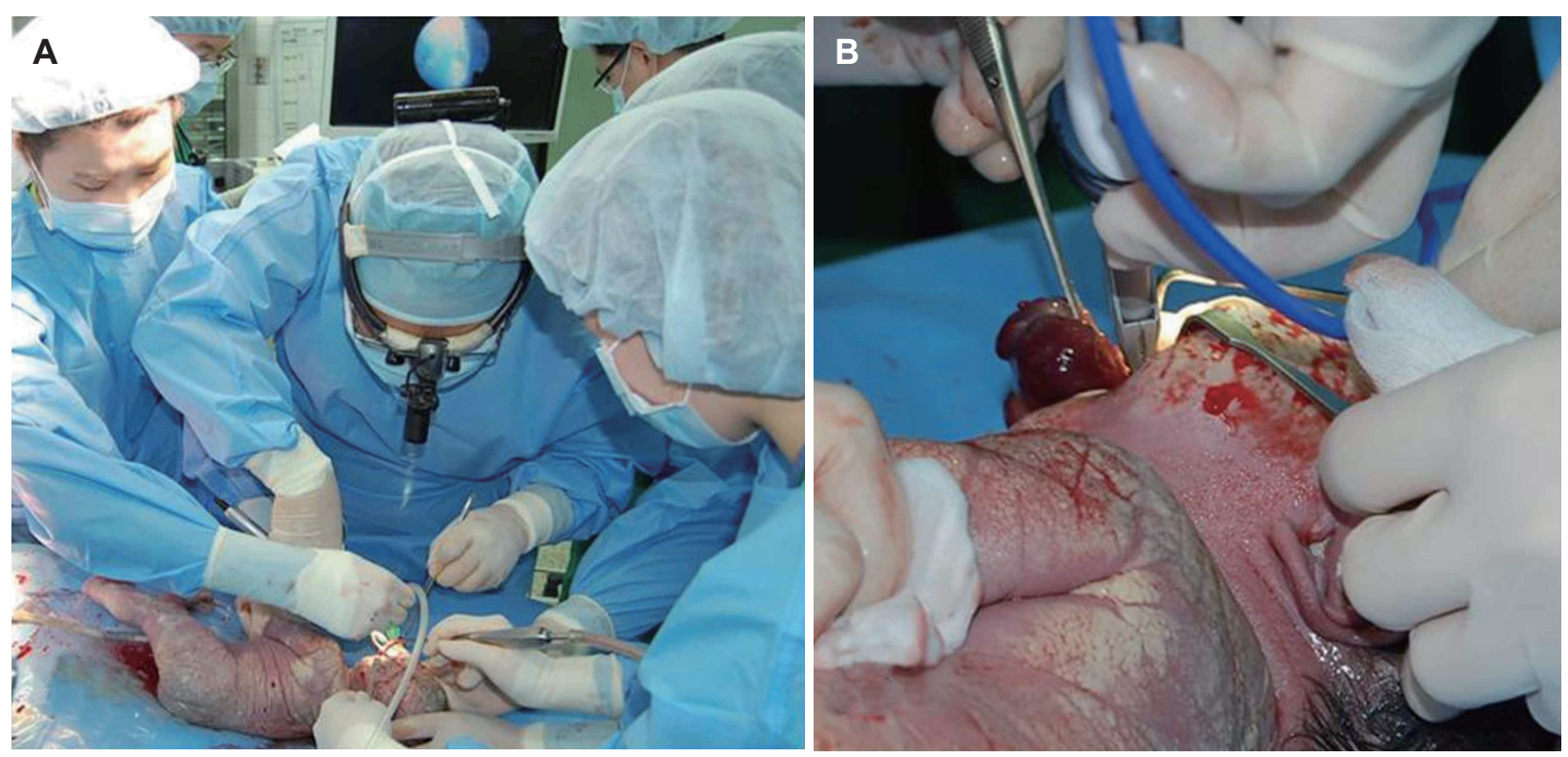

Fig. 3. Immediately, tumor excision was performed by a Head and Neck surgeon (A). Tumor which was originated from the hard palate was removed by using Harmonic scalpel ${ }^{\circledR}$ (Ethicon, Greensboro, NC, USA) (B). 


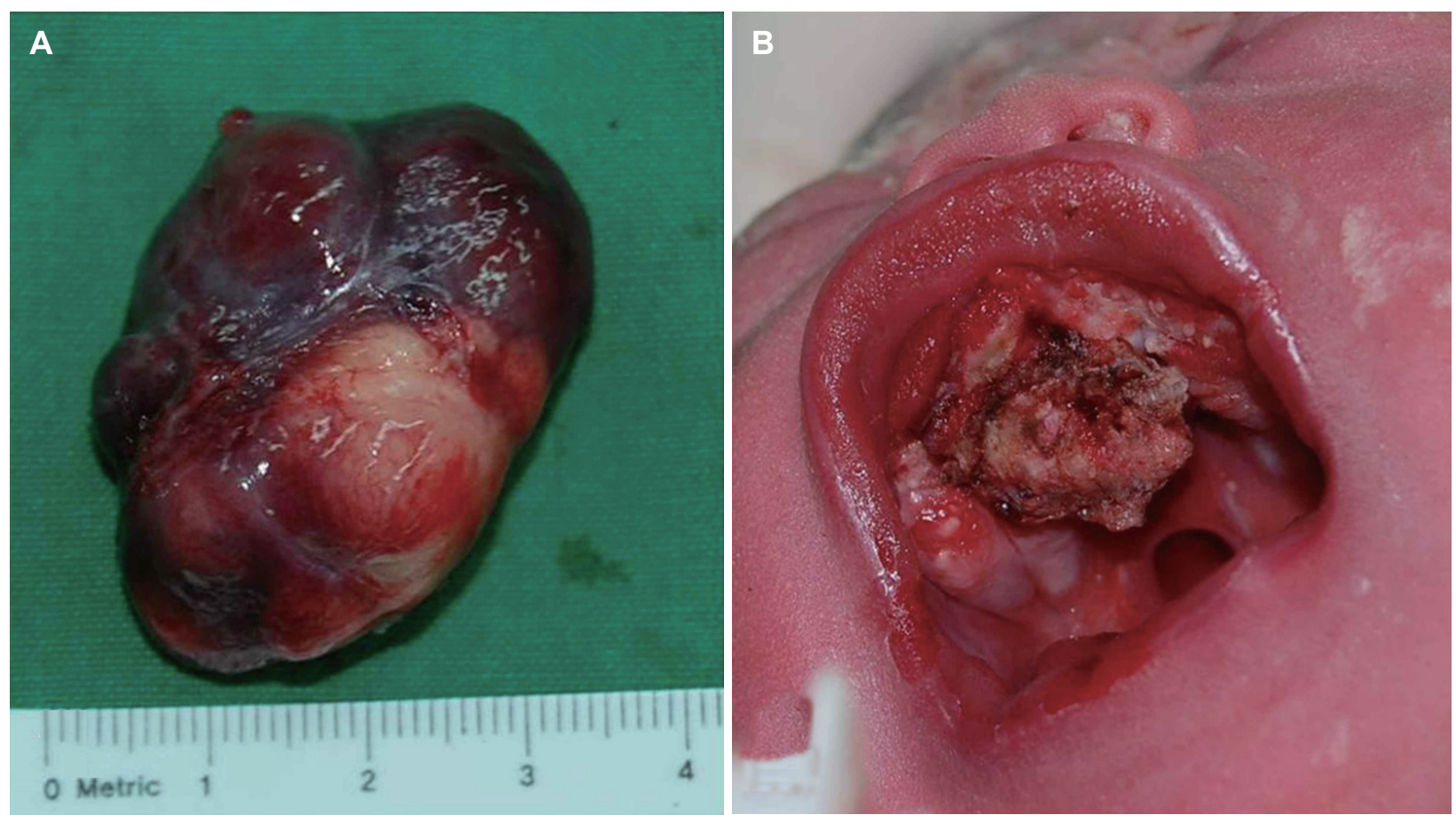

Fig. 4. Postoperative specimen, gross view (A). Fetal airway security was obtained after tumor which originated from the hard palate was removed $(B)$.

소마취 후 종물 제거 시 출혈이 예상되었고 이로 인한 흡인(aspiration) 위험을 고려하여 절제와 지혈을 동시에 진행할 수 있도록 Harmonic scalpel(Ethicon, Greensboro, NC, USA)을 사용하였다. Harmonic scalpel(Ethicon, Greensboro, NC, USA)을 사용하여 종물의 부착부위를 절제하여 종물을 제 거하였다(Fig. 4). 종물로 인하여 태아의 입은 완전히 닫히지 못하는 상태로 구강 내로 접근은 수월하게 이루어졌으며 종 물을 가볍게 아래로 당기면서 기시부를 확인할 수 있었다. 종 물을 제거한 즉시 산소포화도측정기(pulse oxymeter)를 장착 하여 태아의 동맥산소포화도를 확인하였고 기도삽관을 준비 하여 만일의 사태에 대비하였다. 태아의 심박동수와 호흡이 정상 상태인 것을 확인하고 탯줄을 결찰하였다. 제왕절개를 시작하여 태아 만출까지 5 분의 시간이 소요되었고 종물 제거 에 2 분 30 초의 시간이 걸려 최종적으로 자궁절개부터 분만 완 료까지 소요된 시간은 대략 7분 30초였다. 분만 후 태아의 1 분, 5 분 Apgar score는 각각 7점, 9점으로 양호하였고 기도삽 관을 시행하지 않은 상태에서도 자발호흡이 가능하며 기도 유지에 어려움이 없었다. 태아의 출생 체중은 $3260 \mathrm{gm}$ 이었고 종물을 제거한 경구개에서 소량의 출혈이 있었으나 쉽게 지혈 되었다(Fig. 4). 분만 후 산모는 안정적인 상태를 유지하였으 며 산모의 출혈량도 $1000 \mathrm{~mL}$ 정도로 수혈이 필요할 정도는 아니었다.

태아는 정밀 관찰을 위해 신생아 중환자실로 옮기고 생후
1일에 잔유조직(remnant tissue) 및 동반 기형을 확인하기 위 해 CT, MRI 검사를 시행하였다. 우측 후비공폐쇄(choanal atresia) 및 구개열(cleft palate)이 동반되어 있었으며 다른 유 전학적 이상을 의심할 소견은 관찰되지 않았다. 제거한 구강 내 종물에서는 정상적으로 분화된 머리카락 및 치아조직이 발견되었고 병리소견상 성숙 기형종(mature teratoma)으로 진 단되었다.

기형종(teratoma)의 재발 가능성을 고려하여 잔유조직의 완 전 제거가 필요할 것으로 판단되었고, 수술 시기에 관하여 가 능한 빠른 시기에 수술을 시행하는 것이 이후 환자의 경과를 보는 데 도움이 된다는 소아과 전문의의 의견에 따라 조기에 수술을 시행하였다. 생후 9일째 전신마취를 시행하여 경구개 의 잔유조직(remnant tissue of hard palate mass)을 제거하 는 수술을 시행하였고 수술 중 및 수술 후 출혈은 미미하였 다. 환자는 신생아 중환자실에서 feeding tube를 통해 식이 하였고 몸무게는 순조롭게 증가하는 양상으로 출생 후 58일 에 퇴원하였다. 퇴원 이후 외래에서 관찰 중으로 생후 1년 이 후에 구개성형술을 고려 중이며 필요 시 우측 후비공폐쇄(choanal atresia)도 같이 교정하는 것을 계획 중이다.

\section{고 찰}

EXIT는 태아에서 제왕절개술 동안에 자궁-태반순환을 유 
지하면서 태아의 기도를 확보하는 방법이다. ${ }^{1)} 1989$ 년 Norris 등에 의해 거대 전경부 종물이 있는 태아에서 최초로 시행되 었다. 초기에는 선천성 횡격막 탈장이 있는 태아에서 폐 성 숙을 촉진시키기 위해 자궁 내의 태아의 기도를 인위적으로 폐쇄시킨 후 분만 시 이를 복구하기 위해 EXIT를 사용하였 다. 그러나 현재 EXIT를 적용할 수 있는 범위는 계속 확대되 고 있다. 두경부의 종괴나 선천성 상기도 폐쇄를 일으킬 수 있는 다른 많은 질환들에 분만과 동시에 기도확보를 위해, 그 리고 분만 직후에 $\mathrm{ECMO}$ 를 사용해야 하는 경우 등에 널리 사용되고 있다. ${ }^{3-5)}$

정확한 산전진찰은 EXIT를 성공적으로 시행하기 위해 반 드시 필요한 과정이다. 최근 초음파 및 자기공명촬영기술이 발전하면서 선천성 태아기형의 산전 진단율이 높아졌다. 초 음파는 일반적으로 가장 널리 사용되고 있으며, 만약 정확한 진단에 어려움이 있다면 자기공명촬영도 고려해야 한다. ${ }^{3-5,9,10)}$ 본 증례에서는 산전 초음파상 구강 내의 종물을 확인할 수 있었고 분만 시 기도확보를 위해 종물을 제거한 후에 다시 재 수술 전 종물의 정확한 범위를 확인하기 위해 연조직에 대한 해상도가 좋은 자기공명촬영을 시행하였다. 영상학적 검사가 발전하면서 더욱 정확한 진단이 이루어질 수 있게 되었고, 치료 를 위한 정확한 계획도 세울 수 있게 되었다.

출생시의 기도폐쇄는 저산소증, 산증을 야기하며 5 분 이상 지체 시 무산소성 뇌손상 또는 사망까지 이를 수 있다. 따라서 상부-하부 기도의 기계적 폐쇄를 유발할 수 있는 기형의 경우 정확한 산전 진단을 통한 예측과 치료 계획을 수립하고 분만 을 시행해야 한다. ${ }^{11)}$ EXIT는 태아의 자궁-태반순환을 유지시 킨 상태로 기도확보 및 상기도의 선천성 이상의 처치를 안전 하게 시행할 수 있도록 하는 처치 방법으로 각각의 경우에 따 라 일부 차이는 있을 수 있으나 반드시 각 파트별 전문가가 팀(team)을 이루어 접근해야 한다. 산부인과, 마취과, 소아과, 소아외과, 이비인후과 등 각 분야의 전문가들의 협진이 필요 하며 추가적으로 경우에 따라서는 영상의학과, ECMO 팀, 이 차 수술을 위한 각각의 과의 협조도 요구된다. ${ }^{3-5,11)}$ 본 증례 에서도 수술 전에 산부인과, 소아과, 마취과, 이비인후과 간의 협진이 이루어졌고 분만 시 생길 수 있는 상황에 대한 구체적 인 계획을 수립한 후 진행하였다. 수술은 각 과의 인원이 대기 한 상태로 진행되었고 계획대로 무사히 진행할 수 있었다.

기도확보를 위한 EXIT가 성공적으로 이루어지기 위해서 마취, 수술시간 그리고 합병증 관리에 대해서도 일반적인 경 우와 다른 여러 요소를 고려하여야 한다. EXIT를 위한 마취 시 태아의 기도확보를 위한 충분한 시간과 적절한 마취상태 를 유지하여야 한다. 또 자궁의 이완을 유지하여 자궁태반혈 류와 태아의 가스교환을 유지해야 한다. 이를 위해 자궁근
이완효과를 가진 흡입마취제를 사용해야 하며, 고농도의 halogenated agents를 사용한다. ${ }^{1,3,4,12)}$ 모체에 대한 감시도 중 요하지만 태아의 생리적인 조건을 유지하기 위해 태아에게도 산소포화도 및 호기말 이산화탄소 분압을 측정하여 정상적 으로 유지되는지 확인하여야 한다.,12) 산모는 태아의 적절한 기도확보가 이루어질 때까지 자궁이 이완된 상태로 유지됨 으로써 자궁무력증(uterine atony) 및 출혈의 합병증이 있을 수 있다. ${ }^{310,12,13)}$ 항상 대량 출혈 시 즉각 대응할 수 있는 혈액 제제를 준비하는 것이 필요하다. Rahbar 등 ${ }^{14)}$ 은 적절한 자궁태반순환은 일반적으로 60 분 정도 유지될 수 있다고 보고하 였다. 하지만 최근 보고된 케이스에 따르면 2.5시간까지 성공 적으로 순환을 유지하였고 성공적으로 수술을 마쳤다고 한 다. ${ }^{3,15)}$ 증례에서 산모의 마취시행 후 태아 만출까지 5 분 정도 가 소요되었고 종물을 제거하는 수술을 시행하는데도 긴 시 간이 필요하지 않다는 판단으로 수술을 진행하였다. 실제 전 체 수술시간은 7 분 30 초 정도였다. 산모의 출혈량도 일반 분 만 시 출혈량인 $1000 \mathrm{~mL}$ 정도로 수혈은 필요하지 않았다.

본 증례에서 산전 초음파상 구강 종물이 관찰되었고, 이 경 우 분만 후 종물에 의한 기도폐색의 가능성이 높다고 판단되 었다. 산부인과, 마취과, 소아과, 이비인후과 의사들이 협진하 여 EXIT를 시행하기로 결정하였다. 태아 만출 후 구강 종물 을 확인하고 기도삽관 또는 즉시 제거수술 시행을 계획하였 고, 실제로 종물을 제거하여 기도를 성공적으로 확보한 케이 스를 경험하여 문헌고찰과 함께 보고하는 바이다.

\section{REFERENCES}

1) Mychaliska GB, Bealer JF, Graf JL, Rosen MA, Adzick NS, Harrison MR. Operating on placental support: the ex utero intrapartum treatment procedure. J Pediatr Surg 1997;32(2):227-30; discussion $230-1$.

2) Skarsgard ED, Chitkara U, Krane EJ, Riley ET, Halamek LP, Dedo $\mathrm{HH}$. The OOPS procedure (operation on placental support): in utero airway management of the fetus with prenatally diagnosed tracheal obstruction. J Pediatr Surg 1996;31(6):826-8.

3) Abraham RJ, Sau A, Maxwell D. A review of the EXIT (Ex utero Intrapartum Treatment) procedure. J Obstet Gynaecol 2010;30(1):1-5.

4) Liechty KW. Ex-utero intrapartum therapy. Semin Fetal Neonatal Med 2010;15(1):34-9.

5) Moldenhauer JS. Ex Utero Intrapartum Therapy. Semin Pediatr Surg 2013;22(1):44-9.

6) Hwang I, Jung HR, Bae JG. A case of intrauterine lingual cyst with successful delivery assisting Ex utero intrapartum treatment procedure. Korean J Perinatol 2014;25(1):22-6.

7) Masaany BM, Ida Sadja'ah S, Norleza AN, Norzi BG, Siti Sabzah MH. Exit: a salvage procedure for intraoral teratoma. Med J Malaysia 2012;67(5):530-1.

8) Norris MC, Joseph J, Leighton BL. Anaesthesia for perinatal surgery. Am J Perinatol 1989;6:39-40.

9) Saadai P, Jelin EB, Nijagal A, Schecter SC, Hirose S, MacKenzie TC, et al. Long-term outcomes after fetal therapy for congenital high airway obstructive syndrome. J Pediatr Surg 2012;47(6):1095-100.

10) Park HJ, Lee JH, Chung SM, Kim HS. A case of the EXIT (ex utero 
intrapartum treatment) procedure in congenital fetal cervical immature teratoma. Korean J Otorhinolaryngol-Head Neck Surg 2008;51(7): 681-5.

11) Laje P, Johnson MP, Howell LJ, Bebbington MW, Hedrick HL, Flake AW, et al. Ex utero intrapartum treatment in the management of giant cervical teratomas. J Pediatr Surg 2012;47(6):1208-16.

12) Ahn J, Kim JK, Yang M. Ex utero intrapartum treatment (EXIT) for fetal intubation with giant neck mass: a case report. Korean J Anesthesiol 2008;55(4):519-22.

13) Laje P, Howell LJ, Johnson MP, Hedrick HL, Flake AW, Adzick NS. Perinatal management of congenital oropharyngeal tumors: the ex utero intrapartum treatment (EXIT) approach. J Pediatr Surg 2013; 48(10):2005-10.

14) Rahbar R, Vogel A, Myers LB, Bulich LA, Wilkins-Haug L, Benson $\mathrm{CB}$, et al. Fetal surgery in otolaryngology: a new era in the diagnosis and management of fetal airway obstruction because of advances in prenatal imaging. Arch Otolaryngol Head Neck Surg 2005;131(5): 393-8.

15) Hirose S, Farmer DL, Lee H, Nobuhara KK, Harrison MR. The ex utero intrapartum treatment procedure: looking back at the EXIT. J Pediatr Surg 2004;39(3):375-80; discussion 375-80. 